\title{
Impact of Training Education Program on Improving of Nurses Performance Regarding Infection Control in Endoscopy Unit
}

\author{
Asmaa A. Abd-Elhamid ${ }^{1}$, Mohamed N. El-khashab ${ }^{2}$, Nadia M. Taha ${ }^{3}$, \\ Maha D Saleh ${ }^{3}$ \\ ${ }^{1}$ Medical Surgical Nursing Department, Faculty of Nursing, Fayoum University, Egypt. \\ ${ }^{2}$ Tropical medicine Department, Faculty of medicine, Zagazig University,Egypt. \\ ${ }^{3}$ Medical Surgical Nursing Department, Faculty of Nursing, Zagazig University, Egypt.
}

Corresponding Author Asmaa A Abd-Elhamid

Mobile:

$+201220751019$

E mail:proffssabry@yah oo.com

Key words: Educational Training Program,

Gastrointestinal Endoscopy, Infection control, Endoscopy Reprocessing
Background and study aim:Endoscopes are complex and reusable devices. Understanding infection control in the context of endoscopy is important in reducing the transmission of infection. This study aims to evaluate the effect of an educational program on improving nurse's knowledge and practice regarding infection control in endoscopy unit at Zagzig University Hospital.

Subjects and methods: A quasi experimental research design was used. The study was conducted in the Endoscopy Unit at Zagazig University Hospitals. The study samples were all available endoscopy nursing staff. First tool was Questionnaire sheet, to assess nurses' knowledge. The second tool was observational checklist to assess nurses' practice.

\section{INTRODUCTION}

The endoscopy itself is not dangerous, but the current cleaning process used between procedures leaves patients susceptible to infection and troubles many healthcare practitioners [1]. The Emergency Care Research Institute, listed that, inadequate reprocessing of endoscopes as one of its "Top 10 Technology Health Hazards," asserted that reprocessing guidelines should be continuously reviewed and technicians should be better trained [2]. Bommarito reported that about $15 \%$ of endoscopes in Untied States (US) hospitals failed to achieve an accepted standard of cleanliness after liquid reprocessing (the prevailing disinfection process used between patient procedures in his study, duodenoscopes were the dirtiest at a $30 \%$ contamination rate, and colonoscopes were the cleanest at a $3 \%$ contamination rate [3].Peery et
Results:this study revealed that two third of nurses were in the age group of more than 40 years with mean age $42.2 \pm 8.4$ years and the majority of the sample had more than 10 years experience. There was improvement in total level of nurses'knowledge and practice regarding infection control with highly statistically significant difference between pre- post and pre-follow up program phase as regarding to infection control.

Conclusion:The implementation of health educational program had improved nurse's knowledge and practice regarding endoscopy infection.

Recommendations: Continuous educational and infection control training programs are recommended in endoscopy units. So incorporation of such interventions apply in all endoscope unite all over Egypt.

al. stated that more than 18.6 million gastrointestinal endoscopies were performed at least every year in the US alone [4]. While The Gastrointestinal Endoscopy Center at Zagazig University Hospital offers a highly specialized medical service for many clients suffering from different GIT problems. The monthly reports of that center indicated that, during the first four months of 2013, more than 500 GIT endoscopy were performed each month[5]. Approximately 3 million health care workers (HCWs) experience percutaneous exposure to blood borne viruses (BBVs) each year. This results an estimated 16,000 hepatitis C, 66,000 hepatitis $B$, and 200 to 5000 human immunodeficiency virus (HIV) infections annually. 
More than $90 \%$ of these infections are occurring in low-income countries and most of are preventable. Several studies report the risks of occupational BBV infection for HCWs in highincome countries where a range of preventive interventions have been implemented. In contrast, the situation for HCWs in low-income countries is not well documented, and their health and safety remains a neglected issue [6].

Nurses have a professional and legal responsibility in preventing cross-infection from reaching to the patient [7]. Teaching and training are essential for the nursing staff members to improve the quality of health care and to acquire new knowledge and skills. Educational programs are considered as means for providing nurses with theoretical and technical information needed to acquire new skills and to continually improve nursing practice. Also help nurses to accept responsibilities for their professional development. The knowledge and practices of nurses in relation to infection control were deficient. The implementation of a specially developed program has led to statistically significant improvements in nurses' knowledge and practices [8].The well-trained nurse is the backbone of a well-organized department. Today's technical and scientific advances in nursing and increasing consumer demand for high quality health care urged the nurse to keep current in a field that is exploding with new information and increases the need for developing nursing staff education [9].

\section{Significance of the study}

Infection control has recently received a considerable amount of attention. Each year, there are more than 2 million healthcare-associated infections causing 90,000 deaths in the United States. Gastrointestinal (GI) endoscopes are used in more than 10 million procedures annually [10], and contaminated endoscopes have been linked to more outbreaks of healthcare-associated infections than any other medical device [11].All staff in any setting where gastrointestinal endoscopy is performed must adhere to infection control principles that will maintain a safe environment, free from the possibility of spreading disease to patients and co-workers. This is true regardless of the setting (hospital, clinic, ambulatory care center, and office), relative to any and all types of gastrointestinal (GI) procedures performed. Each individual who reprocesses instruments should complete the initial infection control orientation and reprocessing competency. Competency review and infection control updates should be validated and documented annually [12].

\section{Aim of study:}

This study aimed to evaluate the effect of an educational program on improving nurse's knowledge and practice regarding infection control in endoscopy unit at Zagazig University Hospital.

\section{SUBJECTSAND METHODS}

\section{Research design:}

A quasi experimental design was utilized in this study.

\section{Research Setting:}

The study was conducted in endoscopy units in Zagazig University Hospitals.

\section{Subjects:}

The subjects of the study compromised of all available endoscopy nursing staff.

\section{Tools for Data Collection:}

Two tools were used for data collection from endoscopy nurse which include:

1- Questionnaire sheet to assess the endoscopy nurses knowledge regarding infection control (Pre, during, and Post) procedure.

2- Observational check list for endoscopy nurses to assess their practice level regarding infection control (Pre, during, and Post) procedure.

\section{Tool I -Interview questionnaire sheet :}

It was developed and written in Arabic language by researcher after reviewing relevant literature and agreed upon by a panel of medical surgical experts to assess nurse's knowledge in form of multiple choice questions. It was divided into two major parts:

Part I: It was developed to assess sociodemographic characteristics of nurses such as age, education, occupation, experience in endoscopy unit, training course regarding infection... etc It is composed of (12) closed ended questions (question 1-12).

Part II: It was developed to assess the endoscopy nurse's knowledge related to infection, chain of infection, Universal Precautions, and principles of aseptic technique, hand wash, waste management, nurses' knowledge about cleaning, level of 
disinfection, sterilization, and endoscopy reprocessing. It is composed of 193 questions.

\section{Scoring System:}

The rating scale was graded as follows: correct answer (1) and uncorrected one \& don't know (zero). Rating scale of all questions was collected. Total score was 215 degrees. Total score represented $100 \%$. It was evaluated as follows:

- $\quad$ Satisfied $>75 \%$

- Unsatisfied $\leq 75 \%$.

\section{Tool II: Observational checklist :}

It was developed by the researcher after reviewing a literature[13-17] to assess nurses' practices of infection control precautions in endoscopy unit.It is consisted of two checklist as following:

I- General observation checklist: for endoscopy nurses. It is consisted of 28 steps;total degrees equal 51 degrees

II- Reprocessing checklist: for endoscopy nurses. It is consisted of 125 steps;total practice steps 161 equal 176 degrees

\section{Scoring System:}

The rating scale was graded as follows: done correctly (1) one degree and not done or if the nurse did it incorrectly (0) zero degree. Total score of all practices were 176 degrees. Total score represented $100 \%$. Rating scale of all practices was collected and distributed as follows:

- Done correctly $>75 \%$

- Not done $\leq 75 \%$.

\section{Pilot study:}

A pilot study was conducted on 4nurses in order to test the clarity and applicability of the study tools. Required modifications were done in the form of adding or omission of some questions. The time needed to fill in the questionnaire was about (30-45 minutes). Nurses involved in the pilot study were excluded from the main study subjects.

\section{Infection control educational program:}

Infection control educational program was developed by the researcher based on the result of the nurses' practice, the related current literature and available structure guidelines. The content of the teaching guidelines included sixteen sessions that divided in two types of sessions: educational and training sessions. An educational program about infection control in endoscopy unit.

\section{General objectives}

By the end of this educational program, the nurses were able to upgrade nurses' knowledge, and practice related infection in endoscopy unit

\section{Program Descriptions:}

The program is designed to be practical in nature addressing the nurses' knowledge and practices necessary for performing infection control measures in the endoscopy unit. The program construction goes through the following phases:

\section{1- Pre-planning phase: Included;}

1. The framework for the program.

2. Setting the program, general and specific objectives.

3. Allocation of the program resources and facilities (Setting and printed materials).

4. Construction of evaluation device to measure the program effectiveness (pre-/ post-test and follow up questionnaire sheet, and observational checklist)

\section{2- Planning phase: Included;}

1. Determining the program strategies (time table of sessions, teaching methods, media used, learner's activities and evaluation methods).

2. Selecting the teaching place (class room, nursing station, endoscopy unit).

3. Determining the program finances (supplied by the researcher such as all printing materials and media.

4. Determining the learning objectives of the program.

5. Determining the learner characteristics.

6. Determining the learning content of the program.

7. Identifying the teaching methods and determine teaching media.

8. Determining the evaluation tools.

\section{3- Implementation phase: Included;}

The implementation of this program was covered over small sessions, including theoretical and practical content developed and selected to meet the participants' needs and correspond to their interaction and level of understanding as stated by the pilot study. Teaching was done through classical lectures and group discussion which were strengthened by demonstrating the role played by using suitable teaching aids prepared specially for the program such as lecture, handout, posters, colored pictures and simulators. 
The program was implemented through the theoretical and practical sessions. Informed participant with time tables as follow:

1. Maintaining of administration acceptance.

2. Timing of the program implementation, which used to be in the morning and the follow up used to be conducted in endoscopy (9 AM o'clock until 1 PM o'clock).

3. Informing the nurses with time table chart.

4. Conducting the program.

The educational program for nurses working in endoscopy unit included a guidance book which covered theoretical and Practical parts through the following items:

\section{Theoretical part included:}

Theoretical part: it covered by two sessions about definition of endoscope, uses, importance, indication, patient preparation, and complication, and two session covered definition of infection, nosocomial infection, chain of infection, disease transmitted through endoscope, tow session about standers universal precautions, and aseptic techniques.

\section{Practical part included:}

Practical part: 10 sessions for practical, it composed of the application of patient preparation before procedure, care during procedure, and care after procedure, endoscopy reprocessing as (pre-cleaning, cleaning, rinsing, disinfection, drying, and storage. Demonstration and re-demonstration several time until correct done of the pre-duringand post endoscopy use.

\section{4- Evaluation phase:}

Evaluation was done immediately post program implementation and after six months of the follow up phase. The follow up was done to assess the nurses knowledge and practice of infection control and prevention in endoscopy unit through comparing the results of the pre, post and follow up phases to assess the continuous effect of educational program and the sheets were answered within 30-45 minutes, then collected.

\section{III- Administrative design:}

An official permission was obtained from Medical director and nursing director of the study setting. After clear explanation about the study title, aim of the study and setting where the study would be conduct and its benefits.

\section{Ethical consideration:}

The purpose of the study was explained to the nurses and oral consent was obtained from them to participate in this study. They were given an opportunity to withdraw from the study without given a reason and they were assured that anonymity and confidentiality of information was protected. Ethics, values, culture, and beliefs were respected.

\section{VI -Statistical Analysis}

All collected data were organized, categorized, tabulated, entered, and analyzed by using SPSS (Statistical Package for Social Sciences); a software program version 15 , which was applied to frequency tables and statistical significance. The statistical significance and associations were assessed using, the arithmetic mean, the standard deviation (SD), Wilcoxon Signed Ranks test ( $\mathrm{Z}$ test), Pearson chi-square test $\left(\mathrm{X}^{2}\right)$ and Pearson Correlation (r) to detect the relation between the variables. Graphs were done for data visualization and using Microsoft Excel.

\section{RESULTS}

Table 1: It was found that two third $66.7 \%$ of nurses were in the age group of more than 40 years with mean age $42.2 \pm 8.4$ years. In relation to the training $63.3 \%$ of them were not receive any training. Meanwhile ninety percent of the sample had completed their Secondary nursing school education while $10 \%$ had Bachelor in Nursing. As regards to occupation most of studied nurses $80 \%$ were staff nurse. As well as majority $93.3 \%$ of the sample had more than 10 years of experience with mean $23.8 \pm 8.6$ years.

Table (1) shows also $60 \%$ of nurses had medical examination pre working, while only $10 \%$ of them had medical examination during working. Figure 1: shows that regarding to Hepatitis B Vaccination; $76.7 \%$ of study sample were received the vaccine.

Table (2) and Figure (2) show that there was highly statistically improvement in of total nurses knowledge including :infection in general, nosocomial infection, principle of disinfection, infection control precaution, and endoscopy reprocessing when comparing with pre and post, pre and follow up implementation of educational program, at $\mathrm{P} \leq 0.01 * *$. Also represented that total nurses knowledge in per program was $3.3 \%$ only 
satisfactory increased to $80 \%$ in post phase and $70 \%$ in follow up phase of educational program.

Table (3) shows that there were highly statistically improvement of Practice Level regarding standard precaution as hand washing- wear protective cloth (Wear overshoes, wear mask and goggles, wear sterile gown, wear sterile gown, and wear sterile gloves), when comparing with pre and post, pre and follow up of implementation of educational program, at $\left(\mathrm{p} \leq 0.01^{* *}\right)$.

Figure (3) shows that there were highly statistically improvement of practice level regarding adherence to infection control principles restrictedly during procedure as satisfactory level increase from $10 \%$ in pre phase to $83.3 \%$ inpost, pre and follow up of implementation of educational program.
Table (4) Shows that regarding to Nurses' Practices of Infection Control Precautions post endoscopy procedures there were highly statistically improvement of practice level regarding of infection control in all table items namely pre-cleaning, leakage testing, manual cleaning, high level disinfected, manual disinfecting, endoscopy storage, and nurses total post procedure when comparing with pre and post, pre and follow up of implementation of educational program, at $(\mathrm{P} \leq 0.01 * *)$.

Table (5) and figure (4): Illustrated that there were a highly significant statistical improvement of total nurses practice level regarding infection control in endoscopy unit $\left(\mathrm{P} \leq 0.01^{* *}\right)$. As satisfactory level was $0 \%$ in pre-program increased to $80 \%$ post, and $76.7 \%$ follow up of implementation of educational program.

Table(1): Socio Demographic Characteristic of Studied Nurses n= (30)

\begin{tabular}{|c|c|c|}
\hline Socio Demographic Characteristic & No (30) & $\%$ \\
\hline $\begin{array}{l}\text { Age groups (in years) } \\
<40 \mathrm{y} \\
>40 \mathrm{y}\end{array}$ & $\begin{array}{l}10 \\
20\end{array}$ & $\begin{array}{c}33.3 \% \\
66.7\end{array}$ \\
\hline $\begin{array}{l}\text { Range } \\
\text { Median } \\
\bar{X} \pm \text { SD }\end{array}$ & \multicolumn{2}{|c|}{$\begin{array}{c}27: 57 \\
41.5 \\
42.2 \pm 8.4 \text { years }\end{array}$} \\
\hline $\begin{array}{l}\text { Level of education } \\
\text { Bachelor in Nursing } \\
\text { Secondary nursing school }\end{array}$ & $\begin{array}{c}3 \\
27 \\
\end{array}$ & $\begin{array}{l}10 \% \\
90 \%\end{array}$ \\
\hline $\begin{array}{l}\text { Occupation } \\
\text { Chief of unit } \\
\text { Nursing supervisor } \\
\text { Staff nurse }\end{array}$ & $\begin{array}{c}3 \\
3 \\
24\end{array}$ & $\begin{array}{l}10 \% \\
10 \% \\
80 \%\end{array}$ \\
\hline $\begin{array}{l}\text { Years of experience } \\
<10 \mathrm{y} \\
>10 \mathrm{y}\end{array}$ & $\begin{array}{c}2 \\
28\end{array}$ & $\begin{array}{c}6.7 \% \\
93.3 \%\end{array}$ \\
\hline $\begin{array}{l}\text { Range } \\
\text { Median } \\
\bar{X} \pm \text { SD }\end{array}$ & \multicolumn{2}{|c|}{$\begin{array}{c}6: 40 \\
24 \\
23.8 \pm 8.6\end{array}$} \\
\hline $\begin{array}{l}\text { Training } \\
\text { Attend } \\
\text { Not Attend }\end{array}$ & $\begin{array}{l}10 \\
20\end{array}$ & $\begin{array}{l}33.3 \% \\
63.3 \%\end{array}$ \\
\hline $\begin{array}{l}\text { Medical examination pre working: } \\
\text { Yes } \\
\text { No }\end{array}$ & $\begin{array}{l}18 \\
12\end{array}$ & $\begin{array}{l}60 \% \\
40 \%\end{array}$ \\
\hline $\begin{array}{l}\text { Medical examination during working: } \\
\text { Yes } \\
\text { No }\end{array}$ & $\begin{array}{c}3 \\
27\end{array}$ & $\begin{array}{l}10 \% \\
90 \%\end{array}$ \\
\hline
\end{tabular}




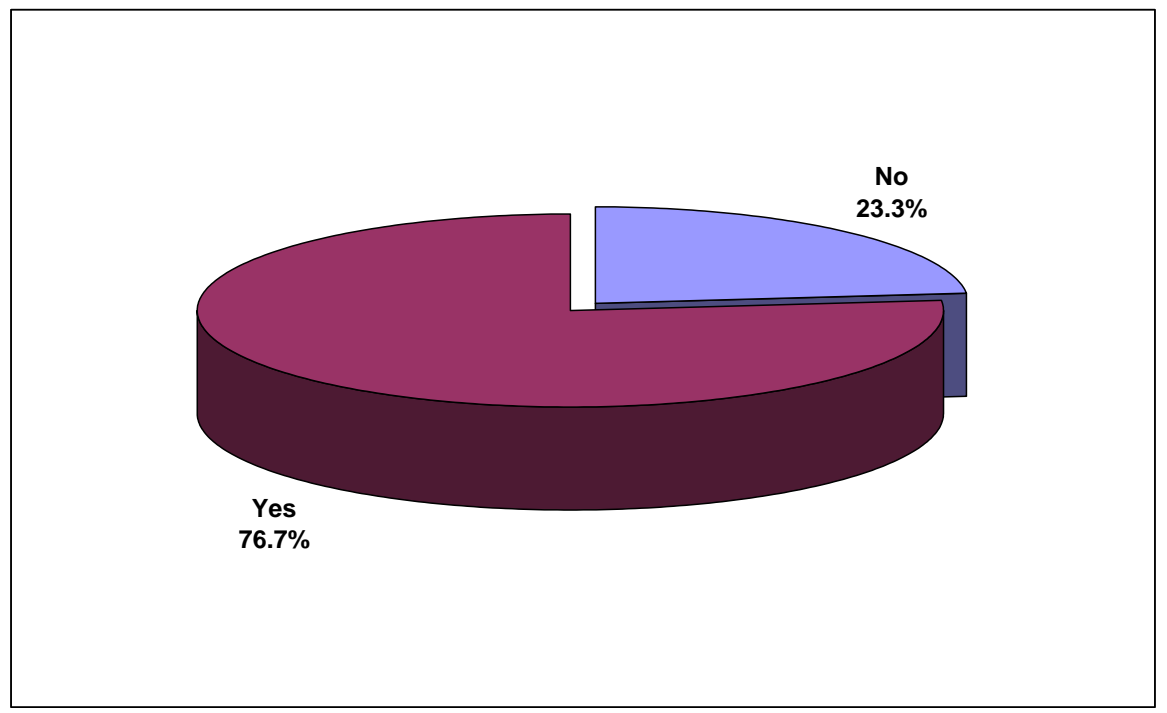

Figure (1) : Hepatitis B Vaccination

Table (2): Total Nurse's Knowledge Regarding Infection Control in Endoscopy Unit Throughout The Study Phases $(\mathrm{n}=30)$ :

\begin{tabular}{|l|c|c|c|c|c|c|c|c|c|c|}
\hline \multirow{2}{*}{$\begin{array}{c}\text { Total } \\
\text { knowledge }\end{array}$} & \multicolumn{4}{|c|}{ Nurses' Knowledge } & \multicolumn{3}{c|}{ Wilcoxon signed rank test } \\
\cline { 2 - 12 } & $\mathbf{2}$ & \multicolumn{2}{|c|}{ Post } & \multicolumn{2}{|c|}{ Follow up } & \multicolumn{2}{c|}{ Pre/Post } & \multicolumn{2}{c|}{ Pre/FU } \\
\cline { 2 - 12 } & $\mathbf{N}$ & $\mathbf{\%}$ & $\mathbf{n}$ & $\mathbf{\%}$ & $\mathbf{N}$ & $\mathbf{\%}$ & $\mathbf{Z}$ & $\mathbf{P}$ & $\mathbf{Z}$ & $\mathbf{P}$ \\
\hline Satisfactory & 1 & 3.3 & 24 & 80.0 & 21 & 70.0 & \multirow{2}{*}{4.79} & $.000^{* *}$ & \multirow{2}{*}{4.26} & \multirow{2}{*}{$.000^{* *}$} \\
\hline Unsatisfactory & 29 & 96.7 & 6 & 20.0 & 9 & 30.0 & & & \\
\hline
\end{tabular}

*Significant at $\mathrm{P} \leq 0.05$ level

**highly significant at $\mathrm{P} \leq 0.01$ level

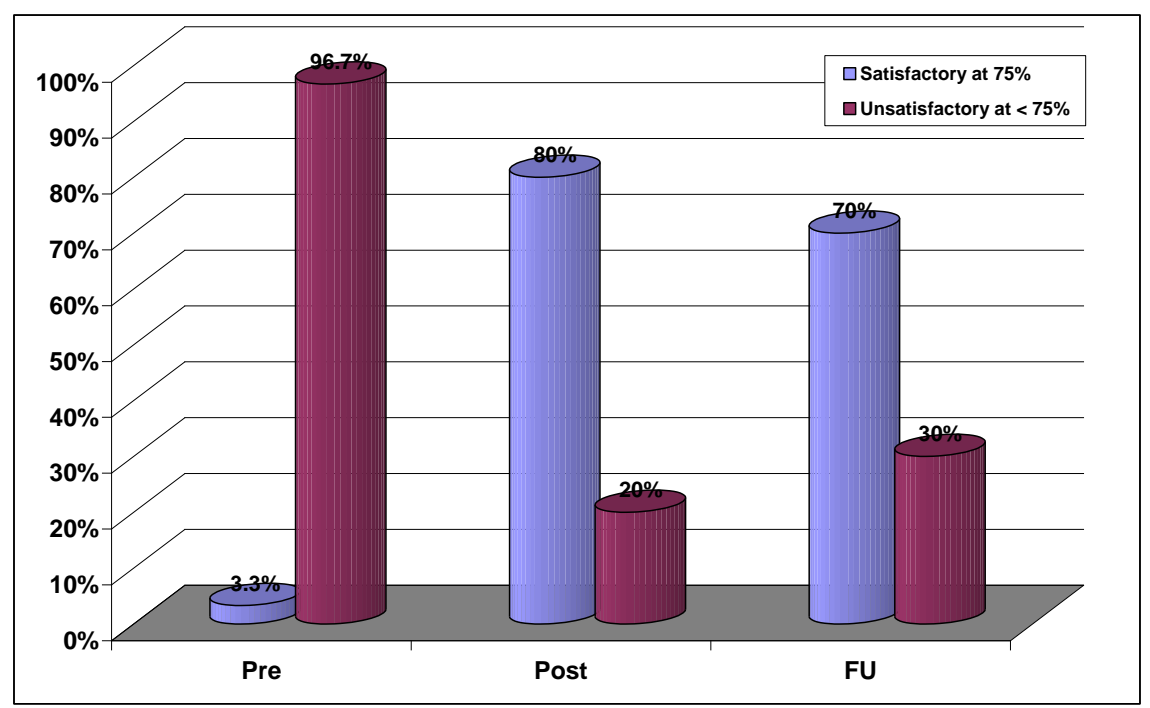

Figure (2):Total nurse's knowledge regarding infection control in endoscopy unit 


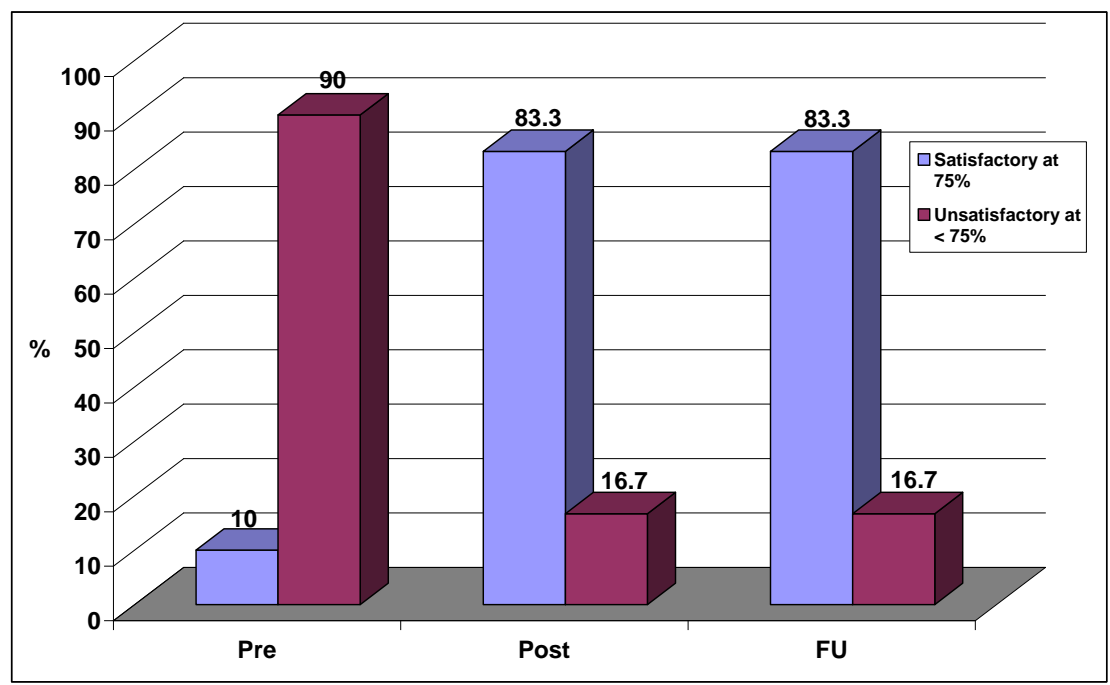

Figure (3):Adherence to infection control principles restrictedly during procedure

Table (3): Frequency Distribution regarding Nurses' Practices of Infection Control Precautions Prior to Endoscopy Procedures Throughout The Study Phases $(n=30)$

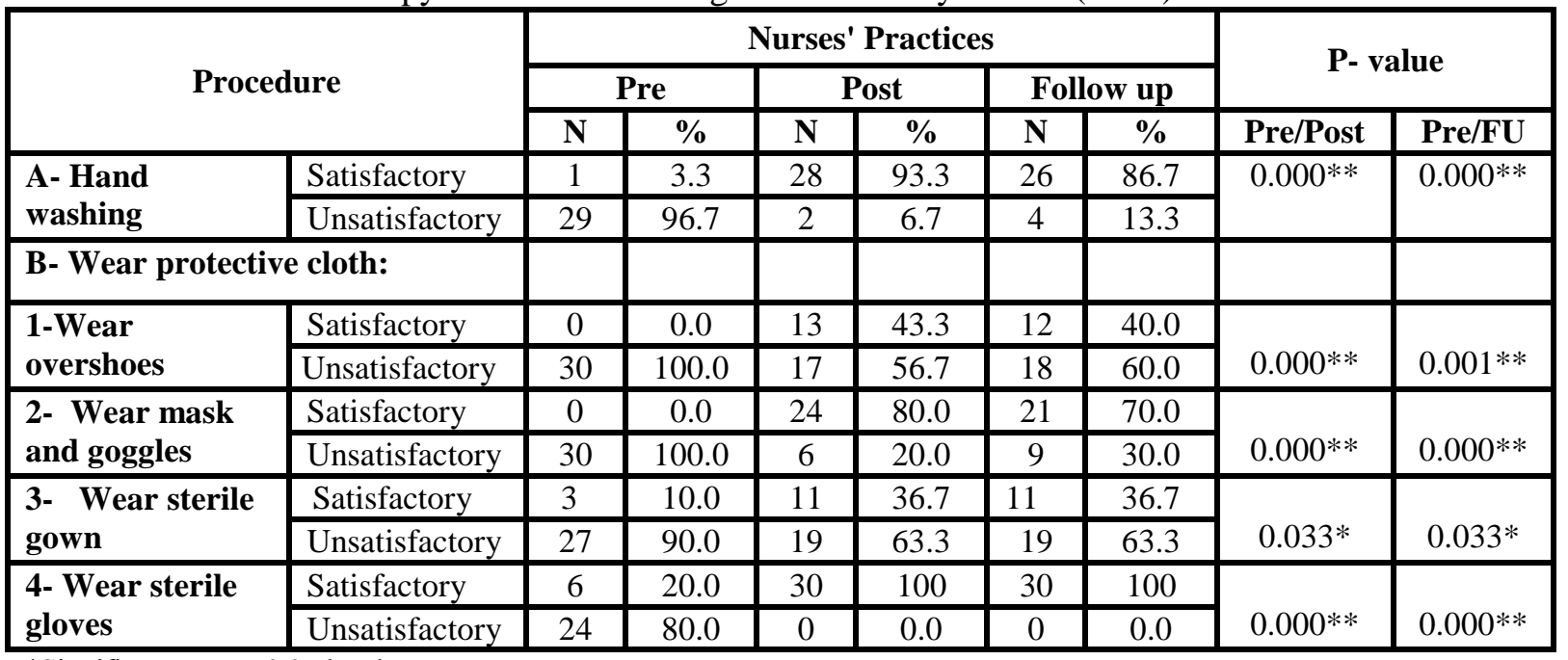

*Significant at $\mathrm{P} \leq 0.05$ level

**highly significant at $\mathrm{P}<0.001$ level 
Table (4): Frequency Distribution of Nurses' Practices regarding Infection Control Precautions Post Endoscopy Procedures

\begin{tabular}{|c|c|c|c|c|c|c|c|c|c|}
\hline \multirow{2}{*}{\multicolumn{2}{|c|}{ Procedure }} & \multicolumn{6}{|c|}{ Nurses' Practices } & \multirow{2}{*}{\multicolumn{2}{|c|}{ p- value }} \\
\hline & & \multicolumn{2}{|c|}{ Pre } & \multicolumn{2}{|c|}{ Post } & \multicolumn{2}{|c|}{ Follow up } & & \\
\hline & & $\mathbf{N}$ & $\%$ & $\mathbf{n}$ & $\%$ & $\mathbf{N}$ & $\%$ & Pre/Post & Pre/FU \\
\hline \multirow[t]{2}{*}{ Pre-cleaning } & \begin{tabular}{|l|} 
Satisfactory \\
\end{tabular} & 2 & 6.7 & 24 & 80.0 & 24 & 80.0 & \multirow[b]{2}{*}{0.000 ** } & \multirow[b]{2}{*}{$0.000^{* *}$} \\
\hline & Unsatisfactory & 28 & 93.3 & 6 & 20.0 & 6 & 20.0 & & \\
\hline \multirow[t]{2}{*}{ Leakage testing } & Satisfactory & 0 & 0.0 & 21 & 70.0 & 21 & 70.0 & \multirow[b]{2}{*}{$0.000 * *$} & \multirow[b]{2}{*}{$0.000 * *$} \\
\hline & Unsatisfactory & 30 & 100 & 9 & 30.0 & 9 & 30.0 & & \\
\hline \multirow[t]{2}{*}{ Manual cleaning } & Satisfactory & 0 & 0.0 & 24 & 80.0 & 23 & 76.7 & \multirow[b]{2}{*}{$0.000 * *$} & \multirow[b]{2}{*}{$0.000 * *$} \\
\hline & Unsatisfactory & 30 & 100 & 6 & 20.0 & 7 & 23.3 & & \\
\hline \multirow{2}{*}{$\begin{array}{l}\text { High level } \\
\text { disinfection }\end{array}$} & Satisfactory & 4 & 13.3 & 22 & 73.3 & 22 & 73.3 & \multirow[b]{2}{*}{$0.000 * *$} & \multirow[b]{2}{*}{$0.000^{* *}$} \\
\hline & Unsatisfactory & 26 & 86.7 & 8 & 26.7 & 8 & 26.7 & & \\
\hline \multirow{2}{*}{$\begin{array}{l}\text { Manual disinfection } \\
\text { and rinse }\end{array}$} & Satisfactory & 0 & 0.0 & 15 & 50 & 14 & 46.7 & \multirow[b]{2}{*}{$0.000^{* *}$} & \multirow[t]{2}{*}{$0.000^{* *}$} \\
\hline & Unsatisfactory & 30 & 100 & 15 & 50 & 16 & 53.3 & & \\
\hline \multirow{2}{*}{$\begin{array}{l}\text { Automated } \\
\text { disinfectionandrinse }\end{array}$} & Satisfactory & 4 & 13.3 & 11 & 36.7 & 11 & 36.7 & \multirow[b]{2}{*}{$0.035 * *$} & \multirow[b]{2}{*}{$0.035^{* *}$} \\
\hline & \begin{tabular}{|l} 
Unsatisfactory \\
\end{tabular} & 26 & 86.7 & 19 & 63.3 & 19 & 63.3 & & \\
\hline \multirow[t]{2}{*}{ Endoscopy handling } & Satisfactory & 25 & 83.3 & 29 & 96.7 & 28 & 70.0 & \multirow[b]{2}{*}{0.102} & \multirow[b]{2}{*}{0.257} \\
\hline & Unsatisfactory & 5 & 13.7 & 1 & 3.3 & 2 & 30.0 & & \\
\hline \multirow[t]{2}{*}{ Endoscopy storage } & Satisfactory & 11 & 36.7 & 30 & 100.0 & 30 & 100 & \multirow[b]{2}{*}{$0.000 * *$} & \multirow[b]{2}{*}{$0.000^{* *}$} \\
\hline & Unsatisfactory & 19 & 63.3 & 0 & 0.0 & 0 & 0.0 & & \\
\hline \multirow[t]{2}{*}{ Total post procedure } & Satisfactory & 0 & 0.0 & 16 & 53.3 & 12 & 40.0 & \multirow[b]{2}{*}{$0.000^{* *}$} & \multirow[b]{2}{*}{$0.001 * *$} \\
\hline & Unsatisfactory & 30 & 100.0 & 14 & 46.7 & 18 & 60.0 & & \\
\hline
\end{tabular}

*Significant at $\mathrm{P} \leq 0.05$ level

**highly significant at $\mathrm{P}<0.001$ level

Table (5): Total Nurses' Practices of Infection Control in Endoscopy Unit Throughout the Study Phases $(n=30)$

\begin{tabular}{|c|c|c|c|c|c|c|c|c|c|c|}
\hline \multirow{4}{*}{ Total practices } & \multicolumn{6}{|c|}{ Nurses' Practices } & \multirow{2}{*}{\multicolumn{4}{|c|}{ Wilcoxon signed rank test }} \\
\hline & \multicolumn{2}{|c|}{ Pre } & \multicolumn{2}{|c|}{ Post } & \multicolumn{2}{|c|}{ Follow up } & & & & \\
\hline & \multirow{2}{*}{$\mathbf{N}$} & \multirow{2}{*}{$\%$} & \multirow{2}{*}{$\mathbf{N}$} & \multirow{2}{*}{$\%$} & \multirow{2}{*}{$\mathbf{N}$} & \multirow{2}{*}{$\%$} & \multicolumn{2}{|c|}{$\overline{\text { Pre/Post }}$} & \multicolumn{2}{|c|}{$\overline{\text { Pre/FU }}$} \\
\hline & & & & & & & $\bar{Z}$ & $\overline{\mathbf{P}}$ & $\bar{Z}$ & $\overline{\mathbf{P}}$ \\
\hline Satisfactory & 0.0 & 0.0 & 24 & 80.0 & 23 & 76.7 & 489 & $0000 * *$ & 497 & $0000 * *$ \\
\hline Unsatisfactory & 30 & 100 & 6 & $\overline{20.0}$ & 7 & 23.3 & & & & \\
\hline
\end{tabular}

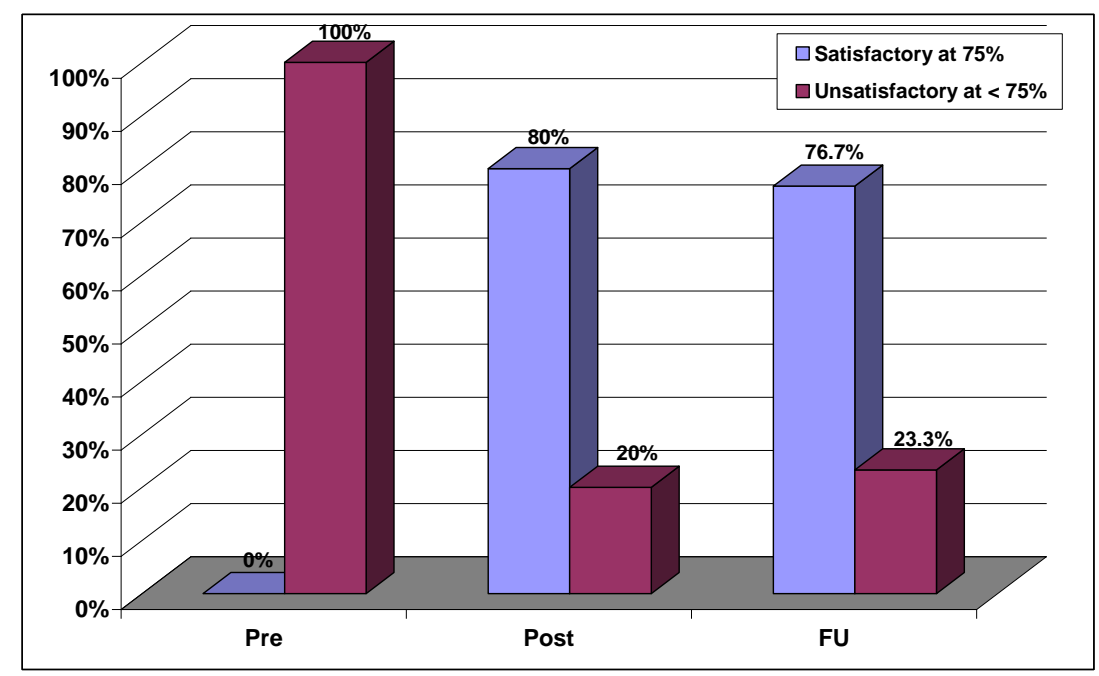

Figure (4): Total Nurses' Practices of Infection Control in Endoscopy Unit 


\section{DISCUSSION}

In relation to nurses' characteristics, the finding of the present study revealed that more than two third of nurses were in the age group of more than 40 years with mean age $42.2 \pm 8.4$ years. This result was in disagreement with Abolwafa et al. who reported that the majority of the studied sample was in the age group from 20-30 years old [18].Also Soliman found, in his study, that less than one third of the nurses were within age group of $25-35$ years with a mean age of $32.61 \pm 5.17$ years [17].

In relation to education level the majority of the sample had completed their secondary nursing school education while only ten percent of them had Bachelor in Nursing. This result was in agreement with El ghatey et al. who found that the majority of nurses had diploma of nursing while minority of them had bachelor degree in nursing [6]. This result was nearly the same as that reported by Abolwafa et al. who reported that most of nurses have Diploma of Secondary Nursing School [18].

As regards to occupation the present study revealed that, most of studied nurses were staff nurse. As well as majority of the sample had more than 10 years of experience with mean $23.8 \pm 8.6$ years. This may be due to stop of supplement new nurses into work in endoscopy unit.All of them were female and about one third of the studied sample had previous attendance to training courses about infection.

These findings in contrast with Soliman who found that, slightly more than half of the nurses had more than 10 years of experience in hemodialysis unit (56.8\%).The highest percentage of the studied nurses did not receive training program about infection control (75.5\%)[17]. This result also was in disagreement with Abolwafa et al. who reported that the current job experience from $5<10$ years. Additionally, about $10 \%$ of the studied sample had previous attendance training courses about infection [18].

Also, Hosoglu et al. mentioned that more than two-thirds of the participants, in their study, had not been trained on the prevention of bloodborne diseases and the risks of occupational injuries[19]. The finding of the current study can be explained in the light of the belief that training within the unit is enough, also it may be due to lack of nurses' interest about the infection control training that done by the infection control team in the hospital. This justify is appreciated by Kandeel et al. who stated that the experience of developing and implementing an infection control (IC) program in Egypt has highlighted many constraints that are common in developing countries, including the lack of trained health care professionals and IC specialists who can implement IC programs[20].

In relation to pre-employment screening and periodic examination during the work, three fifth of nurses had medical examination before working, while only ten percent of them had medical examination during working, thus there is increased risk of spread of infection, absenteeism and disability. This finding goes in the same line with Ghonaiem, and Mohammed who found that the majority of nurses had no pre employment screening and periodic examination during the work[21,22].

Regarding to Hepatitis B Vaccination the current study revealed that, three fourths of study sample were received the vaccine. This is may be due to the increased awarenessof the hospital administration about the importance of the vaccine. Also Ghonaiem, and Mohammed revealed that the majority of nurse had not immunized against viral hepatitis [21,22]. This result is in agreement with EL-Badawy who found that, in the Liver Institute and in Shebin EL Kome Teaching Hospitals, Menofuya, Egypt, about 8\% of nurses had positive hepatitis B surface antigen, $28 \%$ of them had positive anti- hepatitis B surfaces, and $24 \%$ had positive anti-hepatitis C[23]. This finding also consistent with Daniels who mentioned that the nurses should be vaccinated to prevent the potential risk of $\mathrm{HBV}$ [24]. Our results is consistent with those of Duval who assured that, HBV can be prevented by the vaccine [25].

The current results shows that there was highly significant statistical difference regarding the improvement in the total nurses knowledge including (infection in general, nosocomial infection, principle of disinfection, infection control precaution, and endoscopy reprocessing) when comparing pre and post, pre and follow up implementation of educational program, $\left(\mathrm{P} \leq 0.01^{* *}\right)$. This study also revealed that the total nurses knowledge in per program was $3.3 \%$ only satisfactory increased to most of study subject in post phase and more than two third in follow up phase of educational program. 
This findings are in agreement with those of Sliman who mentioned that, there were an improvement in nurses knowledge about infection control precaution throughout the program [26]. Also our results going parallel with those of Soliman who mentions that the majority of nurses were having good level of knowledge about infection control measures after implementation of program regarding infection control [17].

These finding is in agreement with Abd Elaziz et al. who reported an improvement on nurse's knowledge pre and post implementation of the infection control program. There was a statistical significant difference $(\mathrm{p}<0.01)$ between the improvement of nurse's knowledge and the implementation of the infection control program[27]. In additional the present study finding was supported by the study carried out by Marchiam, and Keith who stated that, after implementation of IC program the nursing staff had good knowledge about infection control[28]. This was in line with study done by Mohamed, and Wafa who stated that the results of their study emphasized that scores of knowledge and practice among studied subjects were increased after implementation of the infection control program [29].

The current results revealed that there were highly statistically significant improvement of practice level regarding standard precaution, as hand washing wear protective cloth (Wear overshoes, wear mask and goggles, Wear sterile gown, Wear sterile gown, and Wear sterile gloves) when comparing with pre and post, pre and follow up of implementation of educational program $\left(\mathrm{p} \leq 0.01^{* *}\right)$.

In the same line with these findings Sliman also reported that the majority of observed nurses had adequate practice scores in relation to hand washing, wearing sterile and non sterile gloves. While the least percentage of studied samples had adequate practice related to wear mask. These findings indicate a progressive increase in practice scores after program implementation [26]. This finding supported by study carried by Zatton who showed that $(66.7 \%)$ of their study sample wash their hands with soap and water immediately after contact with blood or other body fluid [30].

These results are in agreement with those of Abd El Lateef who reported a nurses practice score pre/post program implementation regarding wearing protective clothes [31]. Also this is supported by El Ghatey et al. who stated that, as regard to sterile glove technique, minority of nurses showed unsatisfactory level of practice with the same score in the pretests. This could be attributed to the lack of information regarding the importance of using sterile gloves in aseptic technique and lack of motivation [6].

The current results revealed that none of nurses had satisfactory practice in leakage testing, manual cleaning, and - manual disinfecting preprogram and improved to (more than two third, most, and half) of nurses in post program. As regarded to importance of manual cleaning, Society of Gastroenterology Nurses and Associates mentioned that, meticulous manual cleaning of endoscopes and accessories is critical to the success of subsequent disinfection. Manual cleaning refers to the physical removal of organic material and/or soil. The presence of residual organic material and/or soil may protect microorganisms from penetration and destruction by germicides, therefore contributing to disinfection or sterilization failure. This must be beginning immediately after the patient procedure to prevent drying of secretions on both the external surface and inner channels of the endoscope [32].

Similar to this Weber and Rutala reported that, outbreaks associated with flexible endoscopy have most often been associated with breaks in the cleaning and/or disinfection/sterilization stage of flexible endoscope reprocessing [33]. As well Cowen has described how the currently used reprocessing protocols provide a very narrow margin of safety and any slight deviation from the recommended steps may result in an increased risk of infection transmission by flexible endoscopes[34].

In relation to pre-cleaning, and high level disinfection the present study showed that there was a minority of study subject pre- program had satisfactory practice increased to ( most \& near to three fourth) post program implementation. As well Merritt et al. stated that High-level disinfection refers to the use of a disinfectant (e.g., FDA-cleared chemical sterilant or highlevel disinfectant) that inactivates all microorganisms (i.e. bacteria, viruses, fungi, mycobacteria) but not high levels of bacterial spores [35]. Burdick, and Hambrick added that the disinfection process requires immersion of the endoscope in the high-level disinfectant and 
ensuring all channels are perfused for the approved contact time [36].

The current study also showed that regarding automated disinfected and rinse the study represented that minority of nurses in preprogram increased to one third in post program, while endoscopy handling were most of nurses increased to majority post program, and endoscopy storage more than one third increased to $100 \%$ post program. Regarding their total practice, none of the nurses had satisfactory level which improved to half and two fifth in post and follow up respectively.

This finding supported by the study carried by Ali and Taha who reported that, in relation to applying reprocessing steps correctly which include rinsing, storage, documentation and decreasing microbial contamination the results of our study indicated effectiveness of the provided program toward this issues[37].

The current study illustrated that there were a highly significant statistical improvement of total nurses practice level regarding infection control in endoscopy unit, $\left(\mathrm{p} \leq 0.01^{* *}\right)$. As satisfactory level was $0 \%$ in pre - program increased to most of study subject in post program, and more than three fourth in follow up of implementation of educational program. This result was congruent with El ghatey et al. who reported that there were highly statistical significant differences between nurses practice pre and posts program implementation[6]. This result consistent with Ali and Taha who stated that the improvement in nurses' practices after the intervention was also noticeable since their practices before the guidelines were even worse compared with knowledge. In fact none of them had adequate practice at the pre-program phase. Like knowledge, the adequate practice continued throughout the follow-up, and the attendance of the program were the only independent predictors that positively influenced the practice score [37].

\section{CONCLUSION:}

There is improvement in total level of nurses' knowledge, and practice regarding infection control when comparing with pre- post, post/ follow up implementation of educational program.

\section{RECOMMENDATIONS:}

Continuous educational infection control training programs are recommended in endoscopy units.
So incorporation of such interventions apply in all endoscope units all over Egypt.

\section{ACKNOWLEDGEMENT:}

I would like to express my deepest thanks and gratitude to professor Dr Mohamed El-khashab Professor of Tropical Medicine, Faculty of medicine, Zagazig University, professor Dr Nadia Mohamed Taha Assistance professor and the Head of Medical Surgical Department, Faculty of Nursing, Zagazig University, Dr Maha Desoke Saleh Lecturer of Medical Surgical, Faculty of Nursing ,Zagzig University, for unlimited help, constructive criticism, continuous encouragement, continuous assistance and supervision throughout all phases of producing of this work

Funding: None.

Conflicts of interest: None.

Ethical Approval:Approved.

\section{REFERENCES}

1- Centers for Disease Control and Prevention (CDC, 2014): Notes from the field: New Delhimetallo-ß3-lactamase-producing Escherichia coli associated with endoscopic retrograde cholangio-pancreatography. 3 Jan 2014. www.cdc.gov/mmwr/preview/ mmwrhtml/mm6251a4.htm.

2- Emergency Care Research Institute (ECRI, 2014): 2014 top 10 health technology hazards. Health Devices. 2013. www.ecri.org.

3- Bommarito M. A multi-site field study evaluating the effectiveness of manual cleaning of flexible endoscopes with an ATP detection system. Abstract \#040 APIC Annual Conference, 2013.

4- Peery AF, Dellon ES, Lund J, Crockett SD, McGowan CE, Bulsiewicz WJ, et al Burden of gastrointestinal disease in the United States: update. Gastroenterolog 2012; 143:1179-87.

5- Registration Department of Gastrointestinal Center, Zagazig University Hospitals 2013.

6- El Ghatey A, Mahrous F,Gendy J.Impact of Universal Infection Control Intervention Program for Nurses at Asser Hospital Medical-Surgical Nursing Department, Faculty of Nursing, King Khalid University, Abha, Saudi Arabia. Journal of American Science 2013; 9(12) 940:948 http://www.jofamericanscience.org.

7- Elkin M, Perry A , Potter P. Nursing interventions and clinical skills, $2^{\text {nd }}$ ed. $2009, M$ Mosby, Baltimor, 47. 
8- Emam EA, Hassan SA, El-Moghazy D , Mohamed NS. Effect of Educational Program of Paramedicals Knowledge and Attitude toward Infection Control in El-Minia City Hospitals. Doctorate Thesis, Faculty of Nursing, Assiut University, 2005.

9- Derrick S, Inhorn E, Cowan T. The professional developments series, staff nurses survival guide, 2nd ed. 2007, Wolfe Publishing LTD, London, 15 .

10- National Clinical Guideline Centre. Prevention and control of healthcare-associated infections in primary and community care: partial update of NICE Clinical Guideline 2. NICE Clinical Guidelines, No. 139. London: Royal College of Physicians, 2012.

11- Rutala WA, Weber DJ and Healthcare Infection Control Practices Advisory Committee. Guideline for disinfection and sterilization in healthcare facilities. Atlanta, GA: Centers for Disease Control and Prevention, 2008.

12- American Society for Gastrointestinal Endoscopy Quality Assurance in Endoscopy Committee, Petersen BT, Chennat J, Cohen J, Cotton PB, Greenwald DA et al. Multi society guideline on reprocessing flexible gastrointestinal endoscopes. Gastrointestinal Endoscopy 2011,73 (6),10751084.

13- Arenas MD, Sanchez-Paya J, Barri,l G, GarciaValdecasas J, Gorriz JL, Soriano A. A multicentric survey of the practice of hand hygiene in haemodialysis units: Factors affecting compliance. Journal of Nephrol Dial and Transplant 2005; 20 (7):1164-1171.

14- CDC. Transmission of hepatitis B virus among persons undergoing blood glucose monitoring in long-term-care facilities--Mississippi, North Carolina, and Los Angeles County, California, 20032004. Morbdity Mortality Weekly Report 2005; 54(9): 220-223.

15- Schilling JA. Pediatric nursing made incredibly Easy: chronic renal failure. Philadelphia: Lippincott Co. 2005, 400-404.

16- AMSURG 20 Burton Hills Boulevard, Suite 500Nashville, Tennessee37215 (2013).

17- Soliman G.Effect of In service Educational Program for Nurses about Infection Control Precautions on their Practice in Hemodialysis Units. Doctorate Degree in Nursing Sciences, Faculty of Nursing-Mansoura University, 2013, Egypt.
18- Abolwafa FN. Ouda EW. Mohammed ZF,Masoed SE. Developing educational program for Nurses' Related to Infection Control of Invasive Procedures in Neonatal Units at ELMinia University and General Hospitals. J Am Sci 2013;9(10):286-293.

19- Hosoglu, S, Akalin S, Sunbul M, Otkun M.,Ozturk R. Health care workers' compliance with universal precautions in Turkey. Med Hypotheses. 2011;77(6):1079-82.

20- Kandeel A, Rasslan O, Hajjeh R, Hallaj Z, ElSayed N,Mahoneys FJ. Evolution of infection control in Egypt: achievements and challenges. Am J Infect Control 2006; 34 (4): 193-200.

21- Ghonaiem, SE. impact of designed infection control training program of knowledge and practice at Benha university hospital. A thesis submitted for partial fulfillment of doctorate degree, faculty of nursing, Benha University, Egypt, 2011.

22- Mohammed SO. Assessment of Infection Control Measures Practiced by Nurses in The Labor and Delivery Unit Master Thesis at Faculty of Nursing. Benha University, Egypt, 2007.

23- EL-Badawy AM. Assessing the Needle Stick Injuries and Level of Knowledge about Hepatitis B Vaccine among Nurses in Menofuya University Hospital. The New Egyptian Journal of Medicine 2003; 29,(6):7-16.

24- Daniels R. Nursing Fundamentals: Caring \& Clinical Decision Making, 1st Ed. 2004, Thomson Delmar Learning, USA, P 509-512.

25- Duval L. Infection control 101. Nephrology Nursing Journal 2010, 37(5), 485-489.

26- Sliman WM. Implementing and Evaluating Training Program on Infection Control for Nurse's at Intensive Care Units. Unpublished Doctorate Degree in Nursing Science. Faculty of Nursing, Zagazig University, 2010. Pp.34-44, 87105.

27- AbdElaziz M, Soliman, RA, El lawindi M. Evaluation of an Isolation Program of Hepatitis C Virus Infected Hemodialysis Patients in Some Hemodialysis Centers in Egypt. ISRN Nephrology 2013; 395467

28- Marchiam D, Keith K. Infection and Antimicrobial Resistance in the Intensive Care Unit Epidemiology and Outcomes.Anti Microbe Agents 2012; 52:141. 
29- Mohamed SA,Wafa AM. The Effect of an Educational Program on Nurses Knowledge and Practice Related to Hepatitis C Virus: A Pretest And Posttest Quasi-Experimental Design Australian Journal of Basic and Applied Sciences 2011; 5(11):564-570.

30- Zatton HK. Impact of implementation of health education program in improving nurses' knowledge and performance about care of viral hepatitis patients admitted in ZagazigUniversityHospital. Doctorate Thesis, Faculty of Nursing. Zagazig University, Egypt 2007.

31- Abd El Lateef AM. Designing / Implementing and Evaluating an Educational Program for Prevention of Infection in Burn Unit. Unpublished Doctor Thesis Faculty of Nursing, Zagazig University, Egypt, 2003, Pp.69-70.

32- Society of Gastroenterology Nurses and Associates. Standards of infection control in reprocessing of flexible gastrointestinal endoscopes, 2012.www.sgna.org/Portals/0/sgna_stand_of_infe ction_control_0712_FINAL.pdf
33- Weber DJ,Rutala WA. Lessons from outbreaks associated with bronchoscopy. J Hosp Infect $2001 ; 22: 403-8$.

34- Cowen AE.The clinical risks of infection associated with endoscopy. Can J Gastroenterol 2001; 15: 321-31.

35- Merritt K, Hitchins VM, Brown SA. Safety and cleaning of medical materials and devices. $J$ Biomed Mater Res 2000; 53:131-136.

36- Burdick JS, Hambrick D. Endoscope reprocessing and repair costs. Gastrointest Endosc Clin N Am 2004; 14:717-724.

37- Ali HZ, Taha MN. Effect of Infection Control Training Program on Nurse's Performance and Microbial Results on GIT Endoscopes. Advances in Life Science and Technology 2014;27:6-16

Peer reviewer: Maysaa Saeed ,Professor of Tropical Medicine and Hepatogastroenterology, Faculty of Medicine, Zagazig University, Egypt. Editor: Mohamad Emara, Assistant Professor of Tropical Medicine and Hepatogastroenterology, Faculty of Medicine, Zagazig University, Egypt 